\title{
Warthin-Like Variant of Papillary Thyroid Carcinoma: An Uncommon Variant
}

\author{
Tarun Kumar $^{1}$, Jitendra S. Nigam ${ }^{1}$, Prerna Tewari ${ }^{2}$, Chandan K. Jha ${ }^{3}$ \\ 1. Pathology, All India Institute of Medical Sciences, Patna, IND 2. Pathology/Lab Medicine, All India Institute of \\ Medical Sciences, Patna, IND 3. Endocrine Surgery, All India Institute of Medical Sciences, Patna, IND
}

Corresponding author: Tarun Kumar, drtarunkumar1998@gmail.com

\begin{abstract}
Papillary thyroid carcinoma (PTC) is one of the most common thyroid malignancy with various histologic variants. Acknowledging the correct histological variant of PTC helps to know about the tumor's nature and prognosis. The Warthin-like variant of papillary thyroid (WLPTC), a newly described histologic variant of PTC, is relatively uncommon. A 16-year-old female presented with complaints of painful thyroid swelling for two years. Fine needle aspiration cytology (FNAC) from the lobes showed lymphocytic thyroiditis features with Hurthle cell change. Sections from the left lobe revealed a diagnosis of a Warthin-like variant of PTC without nodal metastasis. WLPTC is a rare variant having a favorable outcome due to the absence of lymph node metastasis, extra-thyroidal extension, and a low recurrence rate. The correct cytological and histomorphological features are of utmost importance to render the diagnosis of WLPTC for better management.
\end{abstract}

Categories: Pathology, General Surgery, Oncology

Keywords: warthin tumor, salivary gland, thyroid, cytology

\section{Introduction}

Papillary thyroid carcinoma (PTC) is the most common malignant tumor of the thyroid [1]. There are approximately 15 histologic variants of PTC having variable biological behavior and prognosis [1]. The Warthin-like variant of papillary thyroid (WLPTC) is an uncommon tumor characterized by papillae lined by large oncocytic cells with cores having dense lymphoplasmacytic infiltrate $[1,2]$. These tumors have a resemblance to the Warthin tumor of salivary gland origin [1]. The prognosis of WLPTC is the same or less aggressive than that of classical PTC [2-4]. We are presenting a case of WLPTC due to its rarity.

Review began $12 / 05 / 2020$ Review ended 12/21/2020 Published 12/28/2020

๑) Copyright 2020

Kumar et al. This is an open access article distributed under the terms of the Creative Commons Attribution License CC-BY 4.0., which permits unrestricted use, distribution, and reproduction in any medium, provided the original author and source are credited.

\section{Case Presentation}

A 16-year-old female presented with complaints of painful thyroid swelling for two years. She did not give any previous medical, surgical, or family history of thyroid lesion. Physical examination revealed diffuse, firm to hard enlargement of the thyroid (left>right). No neck nodes were palpable. Thyroid function tests were FT3 -- $4.36 \mathrm{pmol} / \mathrm{L}$ (3.5-6.5 pmol/L), FT4 -- $16.48 \mathrm{pmol} / \mathrm{L}(11.5-22.7 \mathrm{pmol} / \mathrm{L})$ and TSH -- $2.07 \mathrm{IU} / \mathrm{mL}$ (0.33-5.5 IU/mL). Ultrasonography (USG) of the neck showed diffuse enlargement of the thyroid gland with extensive vascularity suggestive of multinodular goiter. Fine needle aspiration cytology (FNAC) from both lobes showed lymphocytic thyroiditis features with Hurthle cell change (Figure 1). 


\section{Cureus}

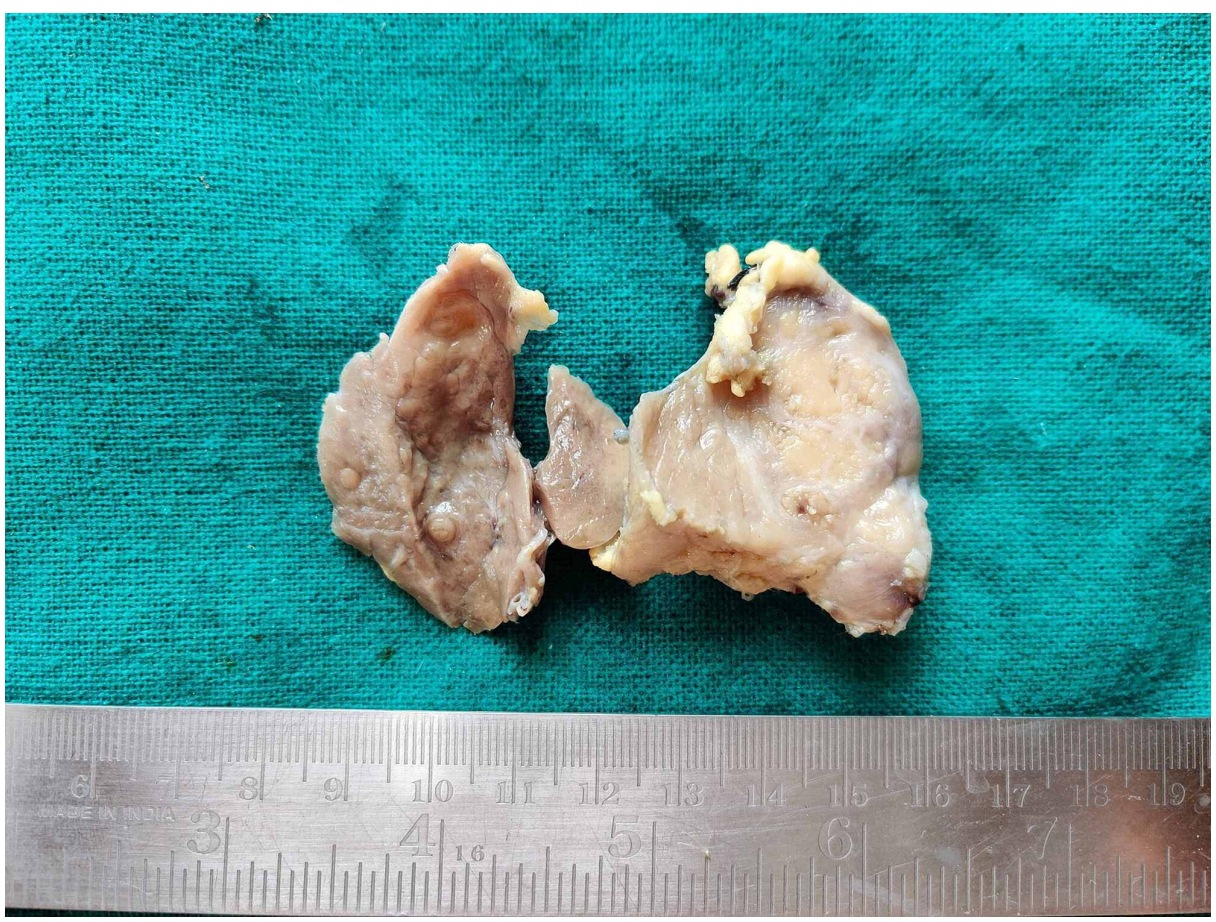

\section{FIGURE 1: Gross: The cut surface of thyroid specimen}

Left lobe: Solid, poorly circumscribed grayish-white lesion.

Right lobe: Gray-brown homogenous areas with two small nodules.

Isthmus: Grayish brown homogenous area.

The patient underwent total thyroidectomy without neck lymph node clearance. Grossly, total thyroidectomy specimen with left lobe, the right lobe, and isthmus measured $4 \times 2.5 \times 3 \mathrm{~cm}, 4 \times 2.5 \times 1.2 \mathrm{~cm}$, and $1.5 \times 1.0 \times 0.5 \mathrm{~cm}$, respectively. The cut surface of the left lobe showed poorly circumscribed, grayish-white solid areas. The right lobe cut surface showed homogenous, gray-brown areas with two small nodules, each measuring $0.4 \times 0.4 \times 0.2 \mathrm{~cm}$. The cut surface of the isthmus showed grayish-brown (Figure 2).
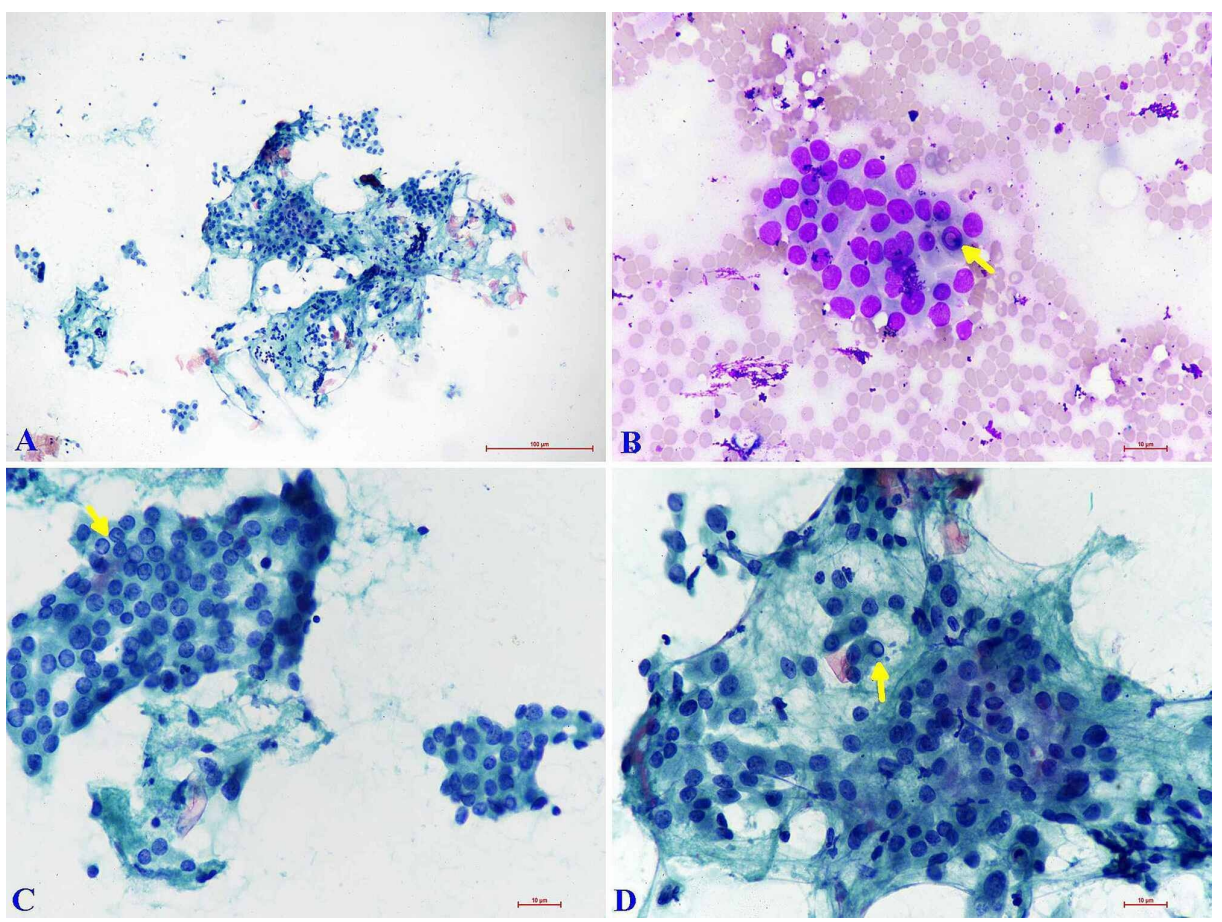

\section{FIGURE 2: Cytology}




\section{Cureus}

(A) Cellular smears showing monolayer sheets of follicular cells with lymphocyte impingement. (Papanicolaou stain: $\mathrm{x} 40$ )

(B) Follicular cells with Hurthle cell change and occasional intranuclear inclusion (arrow). (Giemsa: $\mathrm{x} 400$ )

(C \& D) Follicular cells with mild nucleomegaly having vesicular chromatin, moderate cytoplasm, and an occasional intranuclear inclusion (arrow). (Papanicolaou stain: $x 400$ )

Sections from the left lobe showed a tumor composed of papillae lined by Hurthle cells having an abundant amount of granular eosinophilic cytoplasm and nuclear clearing and grooving with intranuclear cytoplasmic inclusions. The stalk of papillae showed dense lymphoplasmacytic infiltrate (Figure 3).
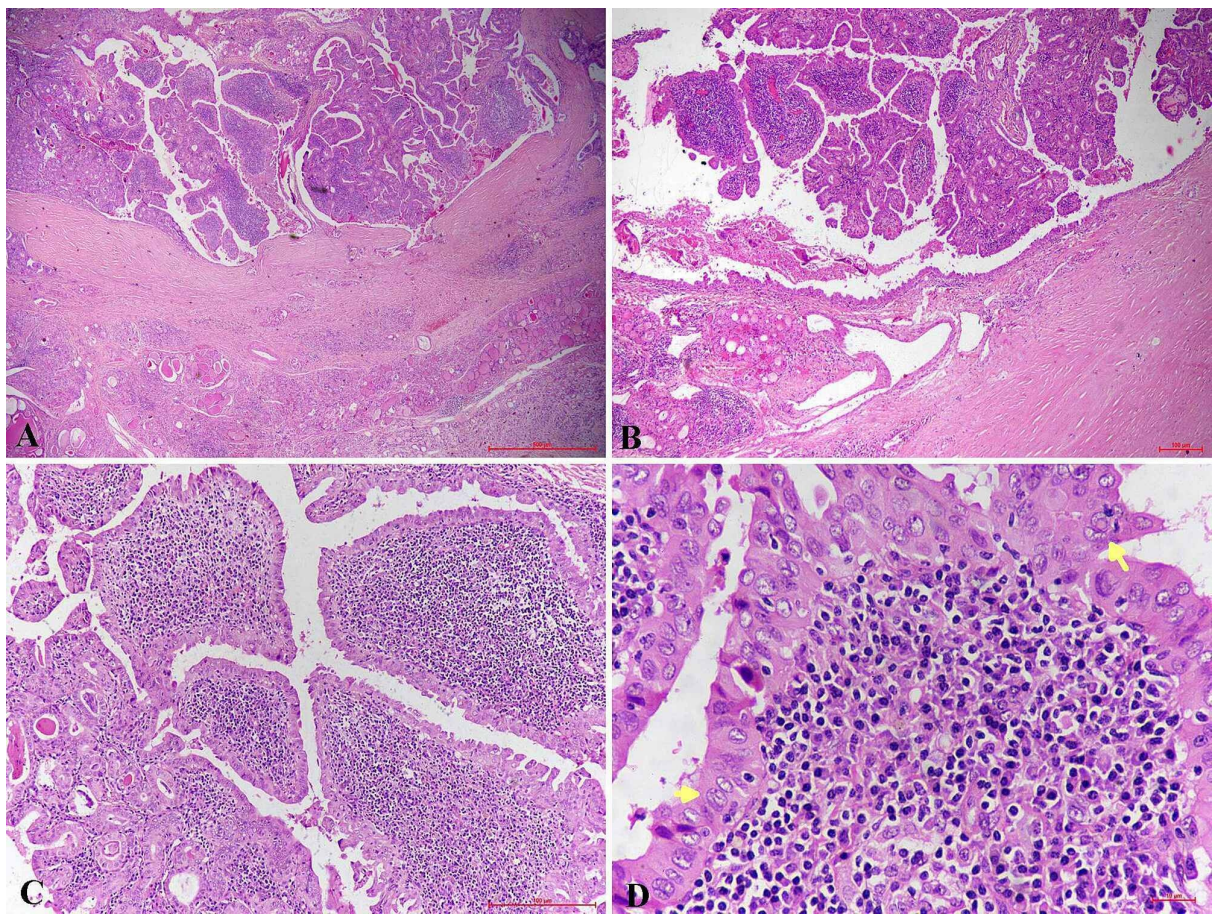

\section{FIGURE 3: Histology}

(A \& B) Poorly circumscribed tumor mass showing numerous papillae. The peritumoral area shows lymphocytic thyroiditis.

(C) Papillae lined by Hurthle cells with stalk showing dense lymphoplasmacytic infiltrate.

(D) Nuclear features of PTC like Intranuclear pseudo inclusion (arrow) and nuclear groove (arrowhead).

PTC: papillary thyroid carcinoma

Sections from the right lobe and Isthmus showed features of lymphocytic thyroiditis. Based on histomorphology, a diagnosis of a Warthin-like variant of PTC of the left lobe was made. Post-operative six months follow-up was uneventful.

\section{Discussion}

In 1995, Apel et al. first described this variant as "papillary Hurthle cell carcinoma of the thyroid with lymphocytic stroma Warthin-like tumor of the thyroid" [2]. Later it was called WLPTC due to its histological resemblance to the Warthin tumor of the salivary gland [2]. The prevalence of WLPTC ranges from $0.2 \%$ to $1.9 \%$, which may be due to misclassification into classical, oncocytic, or Tall cell variant [5-7]. The age of onset ranges from the second to sixth decade (mean: 44.9 years) with a female preponderance [5]. The tumor size varies in range from $3 \mathrm{~mm}$ to $22 \mathrm{~mm}$ with a mean of $8.9 \mathrm{~mm}$ [5]. FNAC features were first described by Youseff et al. in 1997, which includes papillary clusters or monolayered sheets of Hurthle cells with nuclear features of PTC and dense lymphoid cell population in the background [8]. Thus, it shows characteristics of both PTC and Hashimoto thyroiditis [8]. The presence of both features is of utmost essential for cytological diagnosis [8]. In the present case, the patient was 16 years old female harboring a tumor size of $40 \mathrm{~mm}$, 
showing a cellular smear composed of monolayer sheets of Hurthle cells lacking PTC's nuclear features with the presence of lymphocytic infiltrate. Histologically, WLPTC is characterized by papillae lined by large oncocytic cells with cores having dense lymphoplasmacytic infiltrate $[1,2]$. Various studies hypothesized that lymphocytic infiltration is due to the autoimmune mechanism by the presence of RET/PTC fusion gene of PTC $[9,10]$. The differential diagnosis of WLPTC includes Hashimoto thyroiditis, Hurthle cell neoplasm, classical PTC arising in thyroiditis background, tall cell variant, and the oxyphilic variant of PTC [11]. Acknowledging the correct histomorphology has of utmost importance as some of the mimickers have more aggressive and unfavorable outcomes than WLPTC [12]. WLPTC has a favorable outcome due to the absence of lymph node metastasis, extra-thyroidal extension, and a low recurrence rate [13]. Tall cell variants have papillary architecture lined by oncocytes with a height of more than two to three times the width [14]. Oxyphilic variants have papillary architecture lined by Hurthle cell, showing PTC nuclear features with nuclear atypia and hyperchromasia. There is an absence of dense lymphoplasmacytic infiltrate [15]. In the present case, PTC's nuclear features, dense lymphoplasmacytic infiltrate in the papillary core, help to differentiate from Hashimoto thyroiditis, Hurthle cell neoplasm, classical, tall cell, and the oncocytic variant of PTC. As histomorphology is quite characteristics, the role of immunohistochemistry is minimal for a definite diagnosis [3]. BRAF V600E mutation has been implicated in the pathogenesis of classical PTC, while $75 \%$ of WLPTC variant harbor BRAF V600E mutation [16-18]. Depending upon the tumor stage at the time of diagnosis, family history, and neck irradiation history, Total thyroidectomy with/without lymph node dissection is the treatment modality [3]. Post-operative, radioiodine ablation therapy and regular follow-up are employed in high-risk patients having residual thyroid tissue and capsular invasion [3]. The present case was reported because of its rarity as well as to emphasize the problems in the preoperative cytological diagnosis of this rare tumor. Although the sensitivity and specificity of FNAC in the diagnosis of PTC are high, some rare variants like WLPTC may be missed on FNAC [8,19].

\section{Conclusions}

WLPTC is an uncommon variant of PTC regarded as a distinct entity with an excellent prognosis. Hence, the pathologist must identify the cytological and histomorphological features to render the correct diagnosis for better management.

\section{Additional Information \\ Disclosures}

Human subjects: Consent was obtained by all participants in this study. Conflicts of interest: In compliance with the ICMJE uniform disclosure form, all authors declare the following: Payment/services info: All authors have declared that no financial support was received from any organization for the submitted work. Financial relationships: All authors have declared that they have no financial relationships at present or within the previous three years with any organizations that might have an interest in the submitted work. Other relationships: All authors have declared that there are no other relationships or activities that could appear to have influenced the submitted work.

\section{References}

1. Rosai J, Albares Saavedra J, Asioli S, et al.: Papillary thyroid carcinoma. WHO Classification of Tumours of Endocrine Organs. Lloyd RV, Osamura RY, Kloppel G, et al. (ed): IARC Press, Lyon; 2017. 4th edition:81-91.

2. Apel RL, Asa SL, LiVolsi VA: Papillary Hürthle cell carcinoma with lymphocytic stroma. "Warthin-like tumor" of the thyroid. Am J Surg Pathol. 1995, 19:810-814.

3. Paliogiannis $\mathrm{P}$, Attene F, Trogu F, Trignano M: Warthin-like papillary carcinoma of the thyroid gland: case report and review of the literature. Case Rep Oncol Med. 2012, 2012:689291. 10.1155/2012/689291

4. Erşen A, Durak MG, Canda T, Sevınç AI, Saydam S, Koçdor MA: Warthin-like papillary carcinoma of the thyroid: a case series and review of the literature. Turk Patoloji Derg. 2013, 29:150-155. 10.5146/tjpath.2013.01168

5. Jun HH, Kim SM, Hong SW, Lee YS, Chang HS, Park CS: Warthin-like variant of papillary thyroid carcinoma: single institution experience. ANZ J Surg. 2016, 86:492-494.

6. Yeo MK, Bae JS, Lee S, Kim MH, Lim DJ, Lee YS, Jung CK: The Warthin-like variant of papillary thyroid carcinoma: a comparison with classic type in the patients with coexisting Hashimoto's thyroiditis. Int J Endocrinol. 2015, 2015:456027. 10.1155/2015/456027

7. LiVolsi VA: Papillary carcinoma tall cell variant (TCV): a review . Endocr Pathol. 2010, 21:12-15. 10.1007/s12022-010-9106-y

8. Yousef O, Dichard A, Bocklage T: Aspiration cytology features of the warthin tumor-like variant of papillary thyroid carcinoma. A report of two cases. Acta Cytol. 1997, 41:1361-1368. 10.1159/000333538

9. Sarkady E, Sápi Z, Tóth V, Kiss S: Warthin-like tumor of the thyroid a case report . Pathol Oncol Res. 1999, 5:315-317. 10.1053/paor.1999.0214

10. D'Antonio A, De Chiara A, Santoro M, Chiappetta G, Losito NS: Warthin-like tumour of the thyroid gland: RET/PTC expression indicates it is a variant of papillary carcinoma. Histopathology. 2000, 36:493-498.

11. Montone KT, Baloch ZW, LiVolsi VA: The thyroid Hürthle (oncocytic) cell and its associated pathologic conditions: a surgical pathology and cytopathology review. Arch Pathol Lab Med. 2008, 132:1241-1250.

12. Kazaure HS, Roman SA, Sosa JA: Aggressive variants of papillary thyroid cancer: incidence, characteristics and predictors of survival among 43,738 patients. Ann Surg Oncol. 2012, 19:1874-1880. 10.1245/s10434011-2129-x

13. González-Colunga KJ, Loya-Solis A, Ceceñas-Falcón LÁ, Barboza-Quintana O, Rodríguez-Gutiérrez R: 


\section{Cureus}

Warthin-like papillary thyroid carcinoma associated with lymphadenopathy and Hashimoto's thyroiditis . Case Rep Endocrinol. 2015, 2015:251898. 10.1155/2015/251898

14. Tallini G, Giordano TJ.: Thyroid gland. Rosai and Ackerman's Surgical Pathology. Goldblum JR, Lamps LW, McKenney JK, et al. (ed): Elsevier Inc, China; 2018. 11th edition:306.

15. Moreira AL, Waisman J, Cangiarella JF: Aspiration cytology of the oncocytic variant of papillary adenocarcinoma of the thyroid gland. Acta Cytol. 2004, 48:137-141. 10.1159/000326306

16. Kimura ET, Nikiforova MN, Zhu Z, Knauf JA, Nikiforov YE, Fagin JA: High prevalence of BRAF mutations in thyroid cancer: genetic evidence for constitutive activation of the RET/PTC-RAS-BRAF signaling pathway in papillary thyroid carcinoma. Cancer Res. 2003, 63:1454-1457.

17. Amico P, Lanzafame S, Li Destri G, Greco P, Caltabiano R, Vecchio GM, Magro G: Warthin tumor-like papillary thyroid carcinoma with a minor dedifferentiated component: report of a case with clinicopathologic considerations. Case Rep Med. 2010, 2010:495281. 10.1155/2010/495281

18. Panayiotides IG, Foukas PG, Meristoudis C, Zourla AP, Peros G, Karakitsos P: Simultaneous occurrence of Warthin-like papillary carcinoma and lymphoma of the mucosa associated lymphoid tissue in Hashimoto thyroiditis. J Clin Pathol. 2010, 63:662-663. 10.1136/jcp.2010.076299

19. Lyngdoh BS, Mishra J, Dey B, Raphael V, Khonglah Y, Marbaniang E: Role of fine needle aspiration cytology in the diagnosis of papillary carcinoma thyroid: a retrospective study from north-east India. Int J Med Sci Public Health. 2017, 6:1679-1681. 10.5455/ijmsph.2017.0925911102017 